\title{
Studies on in vitro Antagonism of Native Biocontrol Agents on Coconut Stem Bleeding and Bud Rot Disease Pathogens
}

\author{
K. Aruna ${ }^{1}$ and Kalpana Motha ${ }^{2 *}$ \\ ${ }^{1}$ Department of Microbiology, A.S.D Govt. Degree College for Women, \\ Kakinada- 533101, Andhra Pradesh, India \\ ${ }^{2}$ Horticultural Research Station, Dr.YSR Horticultural University, Vijayarai-533475, \\ Andhra Pradesh, India \\ *Corresponding author
}

Keywords

In vitro antagonism,

Trichoderma spp,

Pseudomonas

fluorescens,

Coconut pathogens

Article Info

Accepted:

15 January 2020

Available Online:

10 February 2020

\section{A B S T R A C T}

In vitro antagonism of native biocontrol agents on coconut pathogens revealed that all the three isolated native Trichoderma spp were found inhibitory to the mycelia growth of Thielaviopsis paradoxa and Phytophthora palmivora. Maximum percent inhibition of mycelia growth of Thielaviopsis paradoxa and Phytophthora palmivora was obtained by Trichoderma viride followed by Trichoderma hamatum and Trichoderma harzianum. Pseudomonas fluorescens fared well against the coconut pathogens with the percent inhibition of mycelial growth of pathogen to an extent of 68.32 to $69.38 \%$. Volatile metabolites of Trichoderma spp suppressed the mycelia growth of Thielaviopsis paradoxa and Phytophthora palmivora. In case of non volatile metabolites, significant inhibition of mycelia growth of test pathogens was noticed with Trichoderma spp at $100 \%$ concentration. Studies on the production of volatile and non volatile metabolites of Pseudomonas fluorescens against coconut pathogens revealed that the test pathogens Thielaviopsis paradoxa and Phytophthora palmivora were inhibited significantly. These in vitro studies offers scope for effective management of disease at field level.

\section{Introduction}

Diseases play an important role in palm loss and reduced yields of coconut in India. Even though coconut palm is hardy in nature and adaptable to varied climatic conditions, it is affected by many diseases (Nambiar, 1994, Henry Louis, 2002). Root (wilt) 
(Phytoplasma), basal stem rot (BSR) (Ganoderma spp.), bud rot (Phytophthora palmivora), stem bleeding (Thielaviopsis paradoxa), leaf blight (Lasiodiplodia theobromae) and grey leaf spot (Pestalotiopsis palmarum) are the major diseases of coconut in India. Though a few management practices were available for combating the disease, none of them were effective in eliminating the problem completely. Several group of fungicides have yielded a satisfactory results, but their toxic nature and residual level in the coconut water has not been taken into account largely. Further, indiscriminate use of chemical pesticides or fungicides to cure or prevent plant diseases has caused soil pollution and detrimental effects in humans. Additionally, it eliminates the beneficial soil and biocontrol microorganisms. Biocontrol agents are another alternative for managing the destructive diseases of perennial crops such as basal stem rot disease of coconut (Srinivasulu et al., 2005). Some species of Trichoderma spp. such as $T$. asperellum, $T$. atroviride, $T$. virens, and $T$. harzianum are widely used as biological control agents of many of plant pathogens in coconut and oil palm (Druzhinina et al., 2011). Soil application of Trichoderma viride and Pseudomonas fluorescens talc formulations at the rate of $200 \mathrm{~g}$ each palm in combination with $50 \mathrm{~kg}$ farm yard manure was found effective against basal stem rot in coconut (Kartikeyan et al., 2005). Darmono and Purwantara (2006) reported that an isolate of $T$. harzianum having biofungicidal activity against basal Ganoderma spp. an important pathogen in oil palms. Manjunath et al., (2019) reported that isolates of Trichoderma spp mainly Trichoderma reesei and Pseudomonas spp especially Pseudomonas fluroscence were effective antagonists against basal stem rot disease of coconut. Biological control of plant diseases though gaining importance in the present day agriculture, its adoption in horticultural crops in general and plantation crops in particular is yet to be exploited for many other diseases in coconut. Hence, the present study was taken to exploit native biocontrol agents against stem bleeding and bud rot disease pathogens of coconut and also to study in vitro efficacy of native biocontrol agents against these pathogens of coconut.

\section{Materials and Methods}

\section{Isolation and identification of antagonistic fungi from rhizospheric region of coconut}

Soil samples were collected from rhizospheric region of coconut in Iragavaram and Undaraivarammandals of West Godavari district, Andhra Pradesh. Serial dilution and plate count method was used for isolation of antagonistic fungi. The collected soil samples were subjected to serial dilutions using sterile distilled water and $0.5 \mathrm{ml}$ of each sample at $10^{-3}$ and $10^{-4}$ dilutions were spread on petridishes containing Trichoderma specific medium (TSM) (Elad and Chet, 1983). Two plates were maintained for each dilution. The plates were then incubated at $28^{\circ} \mathrm{C}$ and were examined after four days. Hyphal tip method was adopted for pure culture of organisms. The isolated antagonistic fungi were identified up to the level of genus or species based of growth, color, philides characters on PDA medium and identified as $T$. viride, $T$. harzianum, T. hamatum (Plate-3).

\section{Isolation and identification of antagonistic bacteria}

Samples were serially diluted and $0.1 \mathrm{ml}$ of sample was spread on plates containing King's B medium. The isolate was purified by streaking and was maintained further. Identification of bacterial bioagent was made as per the description and physiological status suggested by Hilderband et al., (1992) and identified as Pseudomonas fluroscence. 


\section{Isolation of coconut pathogens}

The disease symptom of stem bleeding caused by Thielaviopsis paradoxa and bud rot caused by Phytoptera palmivira are depicted in Plate 1. The stem portion of the infected palm where bleeding symptoms were conspicuous was chiseled out and surface sterilized with $0.1 \%$ sodium hypochlorite followed by 3 washes in sterilized distilled water (SDW) and then the stem bits were plated on Potato Dextrose Agar (PDA) media plates for Thielaviopsis paradoxa. Similarly, the bud rot pathogen, Phytophthora palmivora from infected bud tissues were isolated on PDA and were maintained. The plates were the incubated for 3 days at $29+10 \mathrm{c}$ and the test pathogen was isolated by purification (Plate $3 \& 4)$.

\section{In vitro antagonism on fungal pathogens of coconut}

Dual cultures of the fungal antagonists and the test pathogens were prepared by inoculating PDA discs from the growing margins of fresh fungal cultures on to petri dishes containing PDA (Gams et al., 1980) and incubating them. The dual cultures were observed for antibiosis and agar blocks from the regions where the colonies merged were observed for typical interactions under the light microscope.

In case of bacterial antagonists, $8 \mathrm{~mm}$ mycelia discs of the pathogens were placed individually at the center of the plates and bacterial strain was streaked at three positions $2 \mathrm{~cm}$ away from edge of the petri plates with PDA medium and incubated. The mycelia growths of the test pathogens were measured at $48 \mathrm{hrs}$ and subsequently one week after incubation (Nandakumar et al., 2000).

The fungal antagonists that have shown inhibition in dual culture studies were grown on Potato dextrose broth to test the effect of the culture filtrates (nonvolatile metabolites) on the test pathogens by food poisoning technique (Khara and Hadwan, 1990 ). The culture filtrates were purified either by autoclaving at 15 PSI for $15 \mathrm{~min}$. The sterilized filtrate was incorporated in the medium for observing fungal growth and inhibition at different concentration (10\%, $20 \%, 50 \%$ and $100 \%$ ). The PDA mixed filtrate were poured $(20 \mathrm{ml}$ each) into sterilized petridishes and the plates were inoculated with fresh disc of the test pathogens individually.

Mycoparasitism of test pathogen isolates by fungal antagonists was studied using the dual culture technique developed by Dennis and Webster (1971) described by Sanchez et al., 2007. The technique allows the researchers to understand the overall effect of biological control agents. The antagonists were grown on PDA for a period from 0 to 25 days and their effect on growth of test pathogens were tested by exposing inverted plates of freshly inoculated pathogens to plates containing antagonists cultures and sealing together by cello tape. The pathogen growth was measure after 4 days of incubation in both the cases at $29 \pm 1^{\circ}$ cand percent inhibition was calculated by using the formula as given by Vincent (1947).

$\%$ inhibition $=$

Mean growth in control - Mean growth in treatment

Mean growth in control x 100

\section{Results and Discussion}

In vitro antagonism of Trichoderma spp and Pseudonomas fluroscence on coconut pathogens

The results on in vitro antagonism of biocontrol agents on coconut stem bleeding disease pathogen Thielaviopsis paradoxa and 
bud rot disease pathogen Phytophthora palmivora revealed that the percent inhibition of Thielaviopsis paradoxa ranged from 62.90 to $69.35 \%$ and Phytophthora palmivora ranged from 69.38 to $82.03 \%$ by various biocontrol agents (Table 1). It was observed that significantly maximum growth inhibition of Thielaviopsis paradoxawere observed with Trichoderma viride to a percent inhibition of 69.35 followed by Pseudomonas fluroscence to $69.32 \%$ (Plate 3) whereas Trichoderma viridae was effective in arresting the growth of Phytophthora palmivora to $82.03 \%$ closely followed by Trichoderma hamatum to 75.39 $\%$ (Plate 4). The least growth inhibition of Thielaviopsis paradoxa \& Phytophthora palmivora to $62.90 \%$ and $71.87 \%$ respectively was observed with Trichoderma harzianum. The results are in corroboration with earlier workers who reported the potential of biocontrolagent against coconut pathogens (Srinivasulu et al., 2001; Karthikeyan et al., 2005). Palanna et al., (2013) reported that among the 17 biocontrol agents screened, native Trichoderma spp. (V2) recorded $81 \%$ reduction over control in dual culture studies against $G$. applanatum. Trichoderma spp, constitute an important microbial population residing in soil and has been exploited tremendously for management of many soil borne diseases ((Jayaratne et al., 2015; Tapwal et al., 2011). Trichoderma viridae produces several groups of antibiotics, toxins and then the growth of the pathogen is inhibited (Eziashi et al., 2010). Apart from that the direct attack is called mycoparasitism which kills the pathogen by mechanical and chemical means. Also Trichoderma species can inhibit or reduce the growth of the pathogen through competition for space, nutrients or oxygen. Trichorderma is fast growing and has the ability to colonize on a wide variety of substrates that makes the organism efficient soil colonizers and bio- control agents. (Sanchez et al., 2007).Priyaet al., 2012 reported Pseudomonas fluroscene, a potential inhibitory biocontrol agent against Gnanoderma under in vitro conditions. The inhibition of mycelial growth of the pathogen by Pseudomonas fluroscence may be due to the production of antibiotics. Production of antibiotics $\mathrm{HCN}$, pyrrolnitrin, phenazine and 2, 4-diacetyl phloroglucinol and lytic enzymes by Pseudomonas fluroscence against fungal pathogens were reported by many workers (Ramamoorthy et al., 2002; Saravanakumar et al., 2008). George et al., (2012) screened 156 fluorescent pseudomonads against $G$. applanatum and found that $8 \%$ of the total fluorescent pseudomonads showed antagonism towards $G$. applanatum with inhibition ranging from 39 to $73 \%$.

\section{Effect of volatile and non-volatile metabolites of Trichoderma spp on coconut pathogens}

It is noticed from the table 2 that the mycelial growth of Thielaviopsis paradoxa was suppressed when exposed to 25-day-old cultures of Trichoderma hamatum and Trichoderma harzianum with percent inhibition of 70.96 and 75.86 respectively, while Trichoderma viride did not inhibit the mycelial growth of Thielaviopsis paradoxa. None of the three Trichoderma spp were effective against Thielaviopsis paradoxa at zero and 15 days (age) of their exposure. In case of Phytophthora palmivora, maximum suppression was obtained with 25 days old cultures compared to zero days. Trichoderma harzianum of 25 days old cultures suppressed the highest percent $(58.00 \%)$ followed by Trichoderma viride $(56.15 \%)$ and Trichoderma hamatum (54.00 \%) while minimum suppression was noticed with zero days cultures of Trichoderma harzianum $(16.00 \%)$. 
Table.1 In vitro antagonism of native fungal and bacterial agents on coconut pathogens

\begin{tabular}{|c|c|c|c|}
\hline \multirow{2}{*}{ Biocontrol agents } & \multicolumn{2}{|c|}{ Per cent inhibition } \\
\hline & & Thielaviopsis paradoxa & Phytophthora palmivora \\
\hline 1 & T.viride & $69.35^{\mathrm{a}}$ & $82.03^{\mathrm{a}}$ \\
\hline 3 & T. harzianum & $62.90^{\mathrm{d}}$ & $71.87^{\mathrm{c}}$ \\
\hline 3 & T. hamatum & $66.13^{\mathrm{c}}$ & $75.39^{\mathrm{b}}$ \\
\hline 4 & P.fluorescens & $68.32^{\mathrm{b}}$ & $69.38^{\mathrm{d}}$ \\
\hline
\end{tabular}

* Numbers in each column followed by the different letter are significantly different. Values represent the means of 6 replicates

Table.2 In vitro efficacy of Trichoderma spp for production of volatile metabolites against coconut pathogens

\begin{tabular}{|c|c|c|c|c|c|c|c|}
\hline \multirow{4}{*}{\multicolumn{2}{|c|}{ Biocontrol agents }} & \multicolumn{6}{|c|}{ Per cent volatile inhibition } \\
\hline & & \multirow{2}{*}{\multicolumn{3}{|c|}{$\begin{array}{l}\text { Thielaviopsis paradoxa } \\
\text { Days before exposure }\end{array}$}} & \multirow{2}{*}{\multicolumn{3}{|c|}{$\begin{array}{l}\text { Phytophthorapalmivora } \\
\text { Days before exposure }\end{array}$}} \\
\hline & & & & & & & \\
\hline & & $\mathbf{0}$ & 15 & 25 & $\mathbf{0}$ & 15 & 25 \\
\hline 1 & Trichoderma viride & 0 & 0 & $0^{c}$ & $16.25^{\mathrm{c}}$ & $25.00^{c}$ & $56.15^{b}$ \\
\hline 2 & Trichoderma harzianum & 0 & 0 & $70.94^{b}$ & $16.00^{b}$ & $26.25^{b}$ & $58.00^{\mathrm{a}}$ \\
\hline 3 & Trichodermahamatum & 0 & 0 & $75.86^{\mathrm{a}}$ & $18.00^{\mathrm{a}}$ & $27.00^{\mathrm{a}}$ & $54.00^{c}$ \\
\hline
\end{tabular}

Table.3 In vitro efficacy of Trichodermaspp for production of nonvolatile metabolites against coconut pathogens

\begin{tabular}{|c|c|c|c|c|c|c|c|c|c|}
\hline \multirow{4}{*}{\multicolumn{2}{|c|}{$\begin{array}{l}\text { Biocontrol } \\
\text { agents }\end{array}$}} & \multicolumn{8}{|c|}{ Per cent inhibition } \\
\hline & & \multirow{2}{*}{\multicolumn{4}{|c|}{ Concentration of culture filtrate (\%) }} & \multirow{2}{*}{\multicolumn{4}{|c|}{$\begin{array}{l}\text { Phytophthora palmivora } \\
\text { Concentration of culture filtrate (\%) }\end{array}$}} \\
\hline & & & & & & & & & \\
\hline & & 10 & 50 & 70 & 100 & 10 & 50 & 70 & 100 \\
\hline 1 & T.viride & $4.76^{\mathrm{b}}$ & $23.80^{\mathrm{b}}$ & $35.30^{b}$ & $45.56^{\mathrm{b}}$ & $8.32^{b}$ & $23.56^{b}$ & $49.28^{b}$ & $52.00^{\mathrm{a}}$ \\
\hline 2 & T. harzianum & $3.80^{\mathrm{b}}$ & $20.00^{\mathrm{c}}$ & $23.33^{\mathrm{c}}$ & $46.57^{b}$ & $6.86^{\mathrm{c}}$ & $20.00^{\mathrm{c}}$ & $48.00^{c}$ & $49.00^{b}$ \\
\hline 3 & T. hamatum & $21.11^{\mathrm{a}}$ & $37.78^{\mathrm{a}}$ & $41.11^{\mathrm{a}}$ & $76.67^{\mathrm{a}}$ & $12.36^{\mathrm{a}}$ & $35.25^{\mathrm{a}}$ & $50.25^{\mathrm{a}}$ & $51.00^{\mathrm{a}}$ \\
\hline
\end{tabular}

Table.4 Effect of volatile metabolites of $P$. fluorescens on coconut pathogens

\begin{tabular}{|c|c|c|}
\hline \multirow{2}{*}{$\begin{array}{c}\text { Age of antagonist } \\
\text { (days) }\end{array}$} & \multicolumn{2}{|c|}{ Per cent inhibition of coconut pathogens } \\
\hline & T. paradoxa & P. palmivora \\
\hline 0 & 0 & 0 \\
\hline 2 & 0 & 0 \\
\hline 4 & 0 & 0 \\
\hline 6 & $17.91^{\mathrm{a}}$ & $19^{\mathrm{a}}$ \\
\hline 10 & $50^{\mathrm{b}}$ & $60^{\mathrm{b}}$ \\
\hline
\end{tabular}

*Values with different superscripts are significantly different 
Table.5 Effect of non- volatile metabolites of P.fluorescens on coconut pathogens

\begin{tabular}{|c|c|c|}
\hline $\begin{array}{c}\text { Age of antagonist } \\
\text { (days) }\end{array}$ & \multicolumn{2}{|c|}{ Per cent inhibition of coconut pathogens } \\
\hline & $T$. paradoxa & $P$. palmivora \\
\hline 10 & $5^{\mathrm{a}}$ & $8^{\mathrm{a}}$ \\
\hline 20 & $10^{\mathrm{b}}$ & $10^{\mathrm{a}}$ \\
\hline 50 & $40^{\mathrm{c}}$ & $43^{\mathrm{b}}$ \\
\hline 100 & $50^{\mathrm{d}}$ & $52^{\mathrm{c}}$ \\
\hline
\end{tabular}

*Values with different superscripts are significantly different

Plate.1 Disease symptom of stem bleeding (Thielaviopsis paradoxa) on coconutpalm
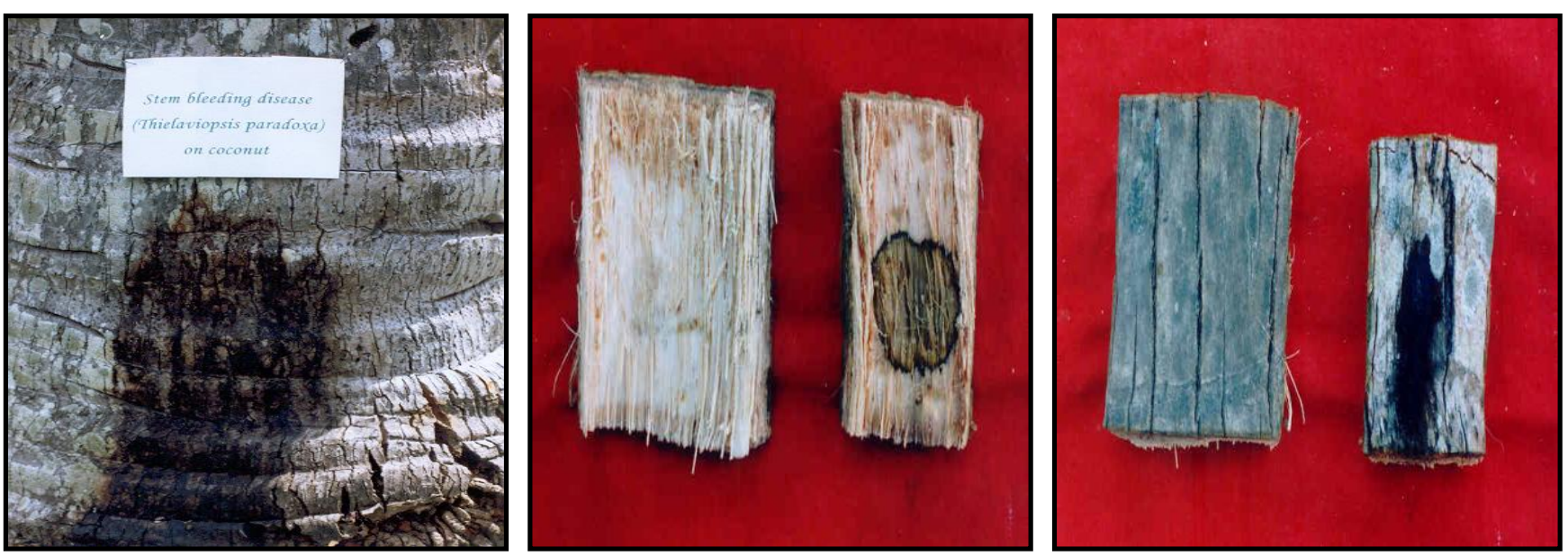

Plate.2 Disease symptom of bud rot (Phytophthora palmivora) on coconut
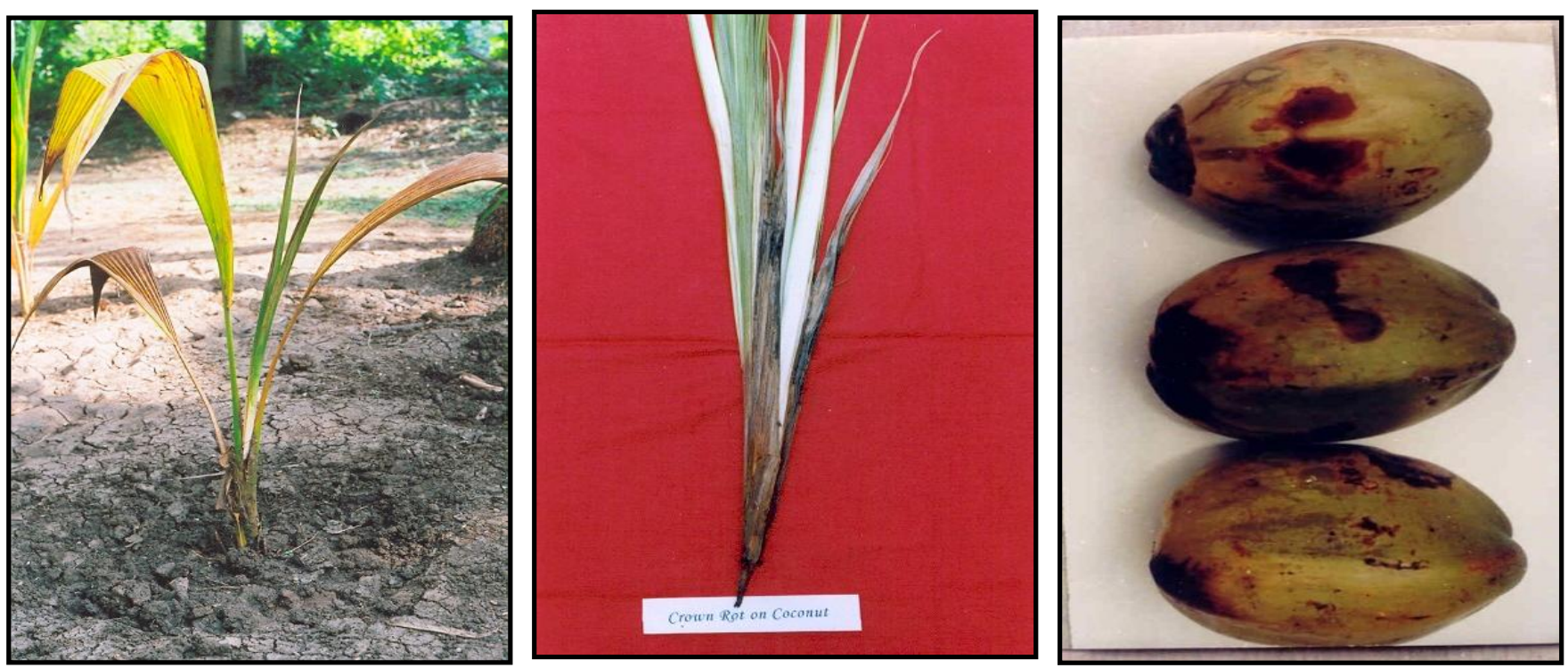
Plate.3 Native isolates of Trichoderma spp.from soil

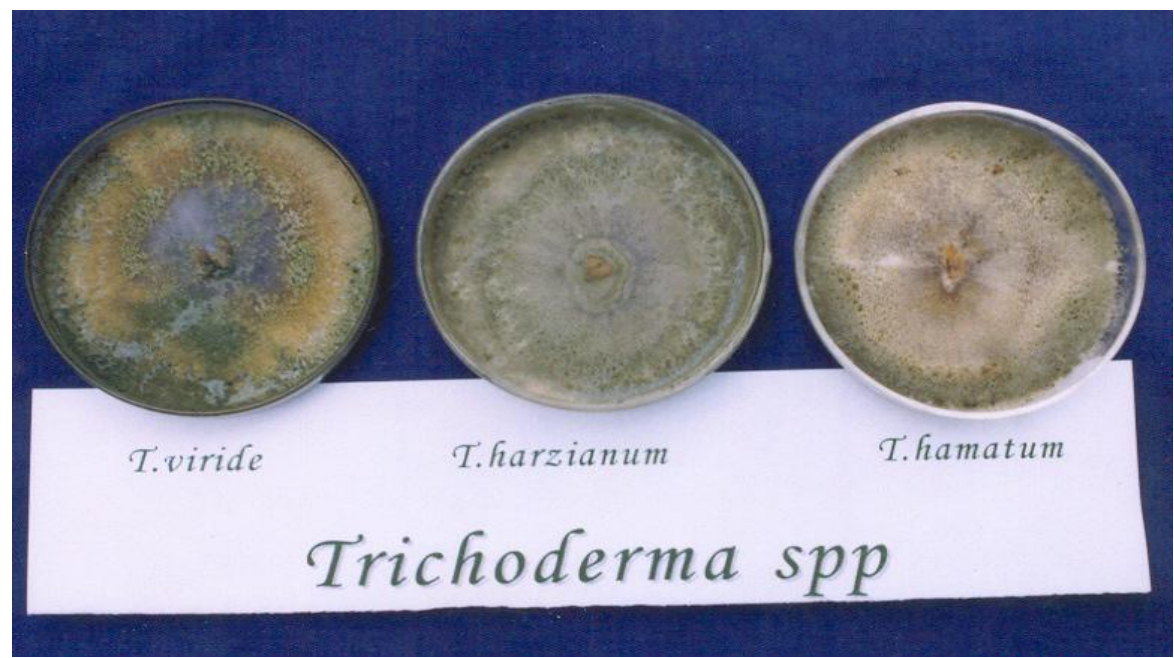

Plate.4 In vitro efficacy of Trichoderma spp and Pseudomonas fluroscence on Thielaviopsis paradoxa
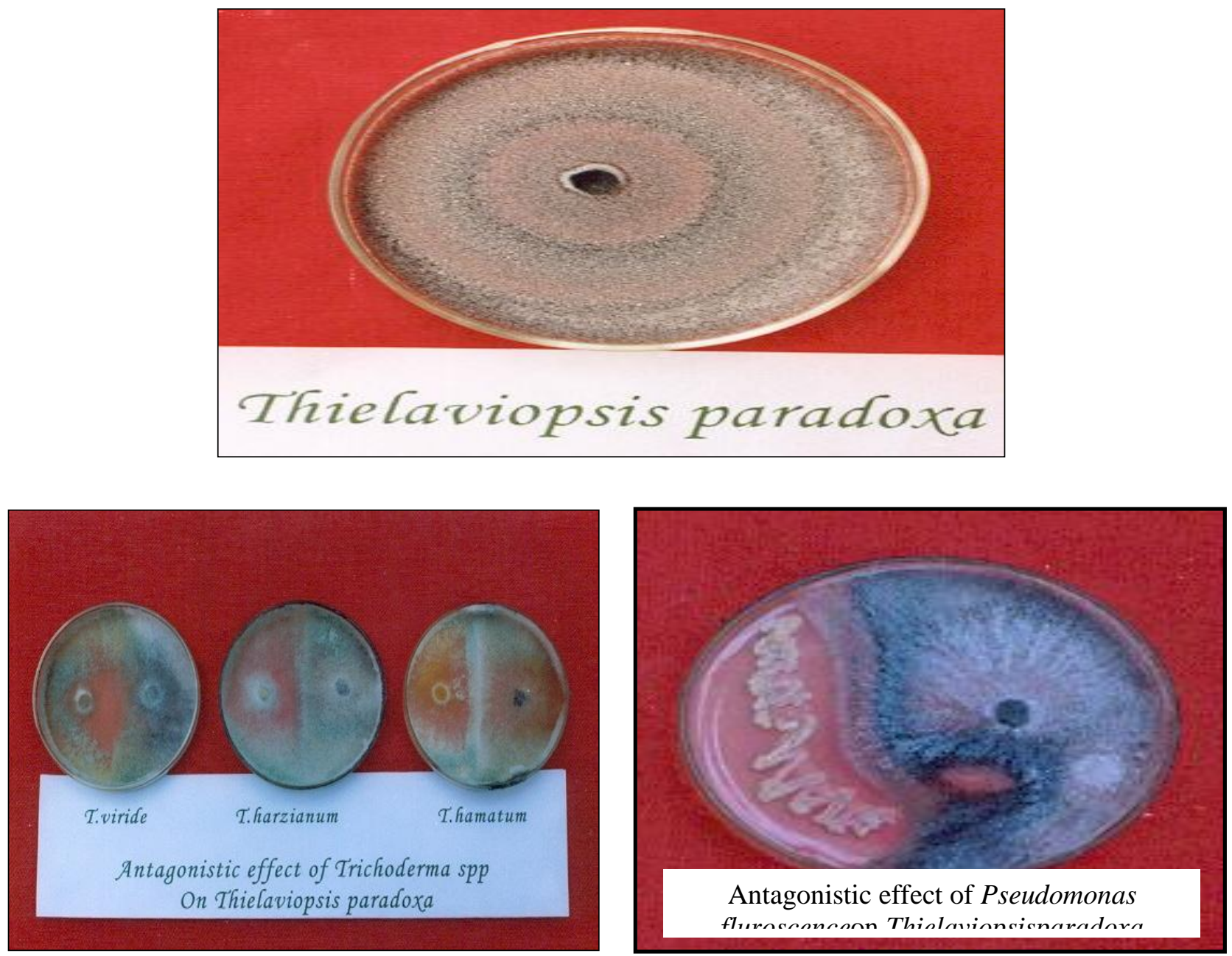


\section{Plate.4 In vitro efficacy of Trichoderma spp and Pseudomonas fluroscence on Phytophthora palmivora}
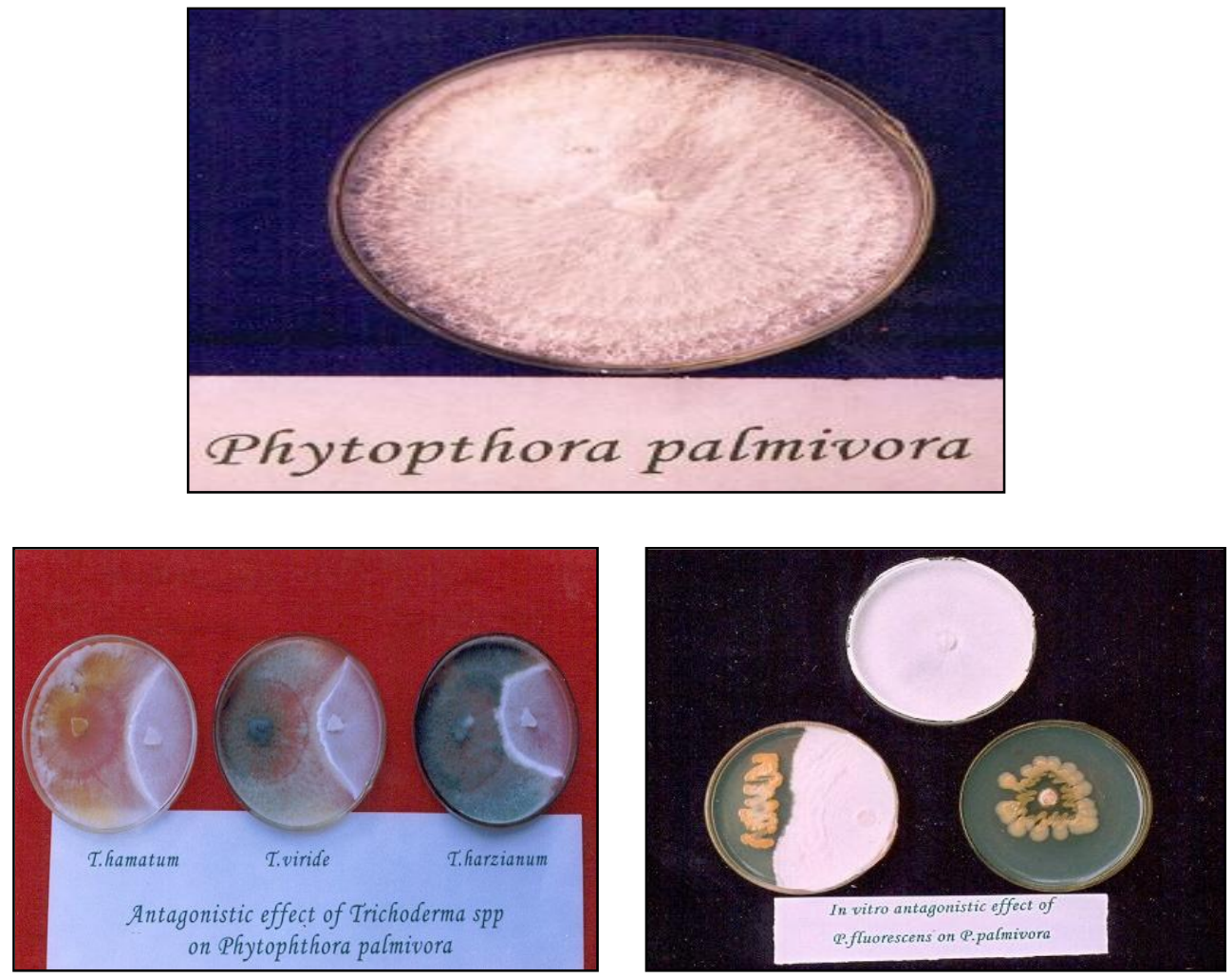

A positive correlation was also obtained between inhibition of the pathogen growth and increased age of the antagonist before exposure to the pathogen. Hyphae from the exposed cultures of the test pathogens when transferred to fresh medium did not grow. The reason attributed may be due to the production of volatile metabolites by the Trichoderma spp i.e. T. viride, T. harzianum and $T$. hamatum which are both fungicidal and fungistatic (Claydon et al., 1987).

In non volatile metabolites, significant inhibition on mycelial growth of Thielaviopsis paradoxa and Phytophthora palmivora pathogens was noticed with all three spices of Trichoderma spp at $100 \%$ concentration of culture filterate (Table 3). The mycelial inhibition of Thielaviopsis paradoxa ranged from minimum with Trichoderma harzianum $(3.80 \%)$ at $10 \%$ concentrate of culture filterate to maximum inhibition (76.67 \%) at $100 \%$ concentrate of culture filterate by Trichoderma hamatum. Similar observations were noticed with the inhibition of mycelial growth of Phytophthora palmivora. Minimum inhibition of mycelial growth of Phytophthora palmivora was noticed with Trichoderma harzianum at $10 \%$ concentration of culture filterate (6.86) whereas maximum with $100 \%$ concentrate of culture filterate of Trichoderma viridae $(52.00 \%)$. A positive correlation was observed between an increase in the concentration of the culture filters of Trichoderma spp and the per cent inhibition in mycelial growth of test pathogens The observation of this study is agreeable with Bourguington (2008) who stated that species of Trichoderma produces nonvolatile metabolites, such as antibiotics and enzymes, which involve in inhibiting growth of pathogenic fungi and spore germination. 
Effect of volatile and non-volatile metabolites of Pseudomonas fluorescens

Studies on the production of volatile metabolites by Pseudomonas fluorescens against coconut pathogens revealed the both the pathogens Thielaviopsis paradoxaand Phytophthora palmivora were inhibited significantly when were exposed to different age old cultures of Pseudomonas fluorescens. The inhibition of Thielaviopsis paradoxa and Phytophthora palmivora was noticed moderately when 6 day old bacterial antagonist was used. The volatile metabolites produced by the antagonist was significantly against Thielaviopsis paradoxa and Phytophthora palmivora with 10 day old bacterial antagonist (Table 4). The nonvolatile metabolites of the Pseudomonas fluorescens against the coconut pathogens was also notice when $50 \%$ concentration and above of the culture filtrate was fortified in the medium. Significant reduction of the coconut pathogens viz., Thielaviopsis paradoxa and Phytophthora palmivora was noticed to a tune of $40 \%$ to $60 \%$ at a concentration of $50 \%$ culture filterate and above concentration of the bacterial antagonist (Table 5). However, the nonvolatile metabolite production was not significant when $20 \%$ and less concentration of the culture filtrate of the antagonist was fortified in the medium.

In nutshell, native biocontrol agents viz., Trichoderma viridae, T.hamatum and T.harzianum screened for antagonism under in vitro are effective against mycelia growth of Thielaviopsis paradoxa and Phytophthora palmivora of coconut. Production and inhibitory effect of volatile substances by the antagonists found a positive correlation between inhibition of the pathogens growth and with usage of aged cultures of the antagonists before exposure to the pathogens. Antagonistic effect of culture filtrate (non- volatile metabolites) of Trichodrema spp against Thielaviopsis paradoxa and Phytophthor apalmivora is by poisoned food technique and inhibition of mycelia growth of test pathogens noticed with all the three species of Trichoderma at $100 \%$ concentration. It offers wide scope for effective management of disease at field level.

\section{References}

Bourguignton, E. 2008. Ecology and diversity of indigenous Trichoderma species in vegetable cropping Canterbury, systems, National Centre for Advanced Bio-Protection Technologies, Lincoln University, New Zealand.

Claydon, N., M. Allan, J.R. Hanson and A.G. Avent. 1987. Antifungal alkyl pyrones of T. harzianum. Trans Br. Mycol. Soc. 88: 503- 513.

Darmono, T. W., Purwantara, A. 2006. Large scale application of growth promoting Trichoderma with biofugicidal activity. $9^{\text {th }}$ International workshop on Trichoderma and Gliocladium book of abstracts Vienna University of Technology April 6-8, Vienn, Austria.

Denis, C. and Webster, J. 1971. Antagonistic properties of species growth of Trichoderma-III. Hyphal interaction. Trans Br. Mycol. Soc., 57: 363-369.

Druzhinina IS, Seidl-Seiboth V, HerreraEstrella A, Horwitz BA, Kenerley CM, Monte E. 2011. Trichoderma: The genomics of opportunistic success. Nature Reviews. Microbiology. 9:749759.

Elad Y. and Chet I.1983.Improved selective media for isolation of spp or Fusariumspp.Phytoparasitica11 : 55-58.

Eziashi, E. I., Uma, N. U., Adekunle, C. E. and Odigie, E. E. 2010. Evaluation of lyophilized and non-lyophilized toxins from Trichoderma species for the control of Ceratocystis paradoxa. 
African Journal of Agricultural Research, 5, 13, 1733-1738.

Gams, W., H.A. Vander A.A., A.J. Vander Plaats-Niterink, R.A. Samson and J.A. Stalpers. 1980. CBS Course of Mycology, second edition. Centraal bureauvo or Schimmel cultures. Baarn, The Nethelands.

George P, Gupta A, Gopal M, Chandra Mohanan R, Thomas L and Thomas G V. 2012. In vitro antagonism of rhizospheric fluorescent pseudomonads of coconut against Ganoderma applanatum and Thielaviopsis paradoxa, fungal pathogens of coconut. Journal of Plantation Crops 40(2): 7581.

Henry Louis, 2002. Coconut- The wonderful palm, PP. 206-18. Hi-Tech Corporation Ramanputhoor, Nagercoil.

Hildebrand, D.C., Schroth, M.N. and Sands, D.C. 1992. Pseudomonas. In. Schaad NW (ed) Laboratory Guide for identification of Plant pathogenic Bacteria, $2^{\text {nd }}$ edition, Americal Phytopathological Society. St. Paul, M.N.

Jayaratne, D. L. and Dayaratne, M. T. A.2015. Phenotypic variability of Ceratocystis paradoxa isolated from North Western and Western Provinces of Sri Lanka and its Bio control by potential bio-control agent; Trichoderma viridae. International Journal of Coconut R \& D, 31, 2, 42-51.

Karthikeyan, G., Karpagavalli, S., Rabindran, R. and Natarajan, C. 2005. Biological control of basal stem rot disease in coconut. The Planter, 81(957): 777-784.

Khara, H.A. and Hadwan, H.A. 1990. In vitro studies on antagonism of Trichoderma spp, against Rhizoctonia solani the causal agent of damping off of tomato. Plant Disease Research. 5 (2): 144 147.

Manjunath Hubballi, Maheshwarappa HP,
Siddappa R and Chandrashekar GS. 2019. Biological control agents for management of basal stem rot in coconut. Journal of Mycology\& Plant Pathology. 49(1): 89-97.

Nambiar K K N. 1994. Diseases and disorders of coconut. (In) Advances in Horticulture, Vol. X - Plantation and Spice Crops Part - 1, Chadha, K L and Rethinam P (Eds). Malhotra Publishing House, New Delhi. Pp: 857-82.

Nandakumar, R., Babu, S., Viswanathan, R., Raguchander, T. and Samiyappan, R. 2000. Induction of systemic resistance in rice against sheath blight disease by Pseudomonas fluorescens. Soil Biol. Biochem.

Palanna K B, Boraiah B, Nagarj M S, Thyagaraj N E and Ramaswamy G R. 2013. Effect of biocontrol agents and botanicals on in vitro growth and development of Ganoderma applanatum. Journal of Plantation Crops 41(2): 151-6.

Priya George, Alka G, MuraliGopal ,R Chandra Mohanan, Litty Thomas and George V.2012. In vitro antagonism of rhizospheric fluorescent pseudomonads of coconut against Gnanoderma applanatum, Thielaviopsis paradoxa fungal pathogens of coconut. $J$ Plantation Crops 40: 75-81.

Ramamoorthy V, Raguchander $\mathrm{T}$ and Samiyappan R 2002. Enhancing resistance of tomato and hot pepper to diseases by seed treatment with fluorescent pseudomonads. 108: 429441.

Sanchez, V., Rebolledo, O., Picaso, R. M., Cardenas, E., Cordova, J. and Samuels, G.J. 2007. In vitro antagonism of Theieloviopsis paradoxa by Trichoderma longibrachiatu. Mycopathologia, 163, 49-58.

Saravanakumar D, Lavanya N, Muthumeena B, Raguchander T, Suresh $\mathrm{S}$ and 
Samiyappan R Pseudomonas fluorescences enhances resistance and natural enemy population in rice plants against leaf folder pest. 132:469-479.

Srinivasulu B, Aruna K, SabithaDoraisamy and Rao DVR. 2001. Occurrence and biocontrol of Ganoderma wilt disease of coconut in coastal agro ecosystem of AP. J Ind Soc. Coastal Agriculture 19: 191-5.

Srinivasulu B, Kumar K V K, Aruna K and Rao D V R. 2005. Biocontrol of basal stem rot (Ganoderma wilt) disease of coconut. Technical Bulletin II, AICRP on Palms, ARS, Ambajipeta, ANGRAU.
Tapwal1, A., Singh, U., De Silva, J. A. T. Singh, G., Garg, S. and Kumar, R. 2011. In vitro Antagonism of Trichoderma viride against five Phytopathogens. Pest Technology 5 (1), 59-62.

Vinale F, Marra R, Scala F, Lorito M, Ghisalberti EL, Sivasithampram K. 2005. Secondary metabolites produced by two commercial strains of Trichoderma harzianum. J Plant Pathology 87:267-309.

Vincent J. M. (1947). Distortion of fungal hyphae in the presence of certain inhibitors. Nature, 159: 850.

\section{How to cite this article:}

Aruna, K. and Kalpana Motha. 2020. Studies on in vitro Antagonism of Native Biocontrol Agents on Coconut Stem Bleeding and Bud Rot Disease Pathogens. Int.J.Curr.Microbiol.App.Sci. 9(02): 2192-2202. doi: https://doi.org/10.20546/ijcmas.2020.902.247 